\title{
Staphylococcus Aureus Infection
}

National Cancer Institute

\section{Source}

National Cancer Institute. Staphylococcus Aureus Infection. NCI Thesaurus. Code C122576.

An infectious process in which the bacteria Staphylococcus aureus is present. 